\title{
A fish otolith assemblage from the Late Miocene (Pannonian) deposits of Lake Pannon (Doba, NW Hungary)
}

\author{
Mariann Bosnakoff \\ Hungarian Academy of Sciences \\ Hungarian Natural History Museum-Eötvös \\ University Research Group for Paleontology, Budapest
}

\author{
Lajos Tamás Katona \\ Natural History Museum of the Bakony Mountains, \\ Zirc
}

\begin{abstract}
A fish otolith assemblage consisting of 173 specimens was recovered from littoral sand deposits of the brackish Lake Pannon at Doba, western Hungary. Co-occurring endemic mollusks indicate the Lymnocardium ponticum Zone, thus an age of about 9 million years (Late Miocene) can be assumed. Most of the investigated otoliths belong to the family Sciaenidae. The otoliths are assigned to 6 taxa: Umbrina cirrhosoides, Umbrina aff. cirrosa, Umbrina sp., "genus aff. Umbrina" kokeni, Morone kuehni?, Gadidae indet. This otolith assemblage does not represent the ancient fish fauna of Lake Pannon, because the common prey fish (gobiids) have not been identified. Generally, the Pannonian fish fauna is characterized by a high number of sciaenid otoliths which indicate a shallow estuarine environment. The fish fauna from Doba is a unique otolith assemblage due to the co-occurrence of several Umbrina species.
\end{abstract}

Key words: fish otoliths, Late Miocene, Lake Pannon, Sciaenidae, Umbrina

\section{Introduction}

Teleost fish remains, mainly isolated fish teeth and otoliths, commonly occur in the Upper Miocene deposits of long-lived Lake Pannon. The first descriptions of fossil otoliths from the Pannonian beds of the Vienna Basin were published by Schubert (1902). Lőrenthey (1905) described three new species from Hungarian localities. His data were mentioned in Schubert's paper along with many other ones (Schubert 1906).

Addresses: M. Bosnakoff: H-1431 Budapest, P.O.Box 137 Hungary, e-mail: bosnakoff@yahoo.com

L. T. Katona: H-8420 Zirc, Rákóczi tér 3-5, Hungary,

e-mail: btmz@bakonymuseum.koznet.hu

Received: September 27, 2011, accepted: April 4, 2012 
Later, systematic studies on Pannonian otoliths and the description of several new otolith-based taxa were presented by Weinfurter (1950; Weinfurter in Papp and Thenius 1954) and the early Pannonian fish fauna was interpreted as a primarily marine relict fauna with only a few freshwater immigrants. He also stated that the freshwater forms became dominant at the end of the Pannonian.

In 1985, Brzobohatý and Pană gave a short review about Pannonian fish faunas, partly based on otoliths. They confirmed Weinfurter's conclusions and added that the Pannonian fauna was impoverished compared to the previous Sarmatian one and consisted of fishes of various marine origin. In addition, endemism caused by geographic isolation was demonstrated in the families Gadidae, Triglidae and Trachidae.

Brzobohatý (1992) reported a few fish otolith taxa from the famous mammal locality of Götzendorf, Lower Austria. Schwarzhans (1993) discussed the distribution of Pannonian otoliths and endemism of the host fishes in his comparative morphological study on recent and fossil sciaenid otoliths. He claimed that endemism is hard to prove in Late Miocene to Early Pliocene Paratethyan sciaenids. Recently, Cziczer et al. (2009) reported an otolith and a partial fish skeleton from Pannonian localities.

In the present paper we report on an otolith assemblage collected from littoral sand deposits of Lake Pannon at Doba, western Hungary, with detailed taxonomic descriptions, which constitutes part of the reconstruction of the Pannonian fish fauna by the primary author.

\section{Locality}

In 2008, a team from the Natural History Museum of the Bakony Mountains of Zirc carried out field work and paleontological exploration around the Somló volcanic butte in the Little Hungarian Plain Volcanic Field (Fig. 1). Two perpendicular exploration trenches, 8 and $12 \mathrm{~m}$ long, respectively, and $2.6 \mathrm{~m}$ deep, were dug northeast of the Somló Butte, near the village of Doba (coordinates: $47.16516^{\circ} \mathrm{N} 17.38408^{\circ} \mathrm{E}$ ). The exposed section starts with $1.5 \mathrm{~m}$-thick yellowish-gray, medium-grained sand, overlain by $0.2 \mathrm{~m}$-thick cross-bedded medium-grained sand. These layers yielded no fossils. The next $0.2 \mathrm{~m}$-thick fine-grained sand contained only a few vertical burrows of the bivalve Lymnocardium. The upper part of the section comprises highly fossiliferous sands that yielded ca. 60 gastropod and 12 bivalve species (Katona and Magyar, in prep.), each representing endemic forms of Lake Pannon, a number of charophytes, fish and other vertebrate remains.

The exposed section belongs to the littoral to deltaic Somló Formation, the "Congeria ungulacaprae Beds" of Strausz (1942), i.e. to the Lymnocardium ponticum Zone (Szilaj et al. 1999) (Fig. 2). Its age is estimated at 8.7-9.6 Ma (Magyar et al. 1999a). 

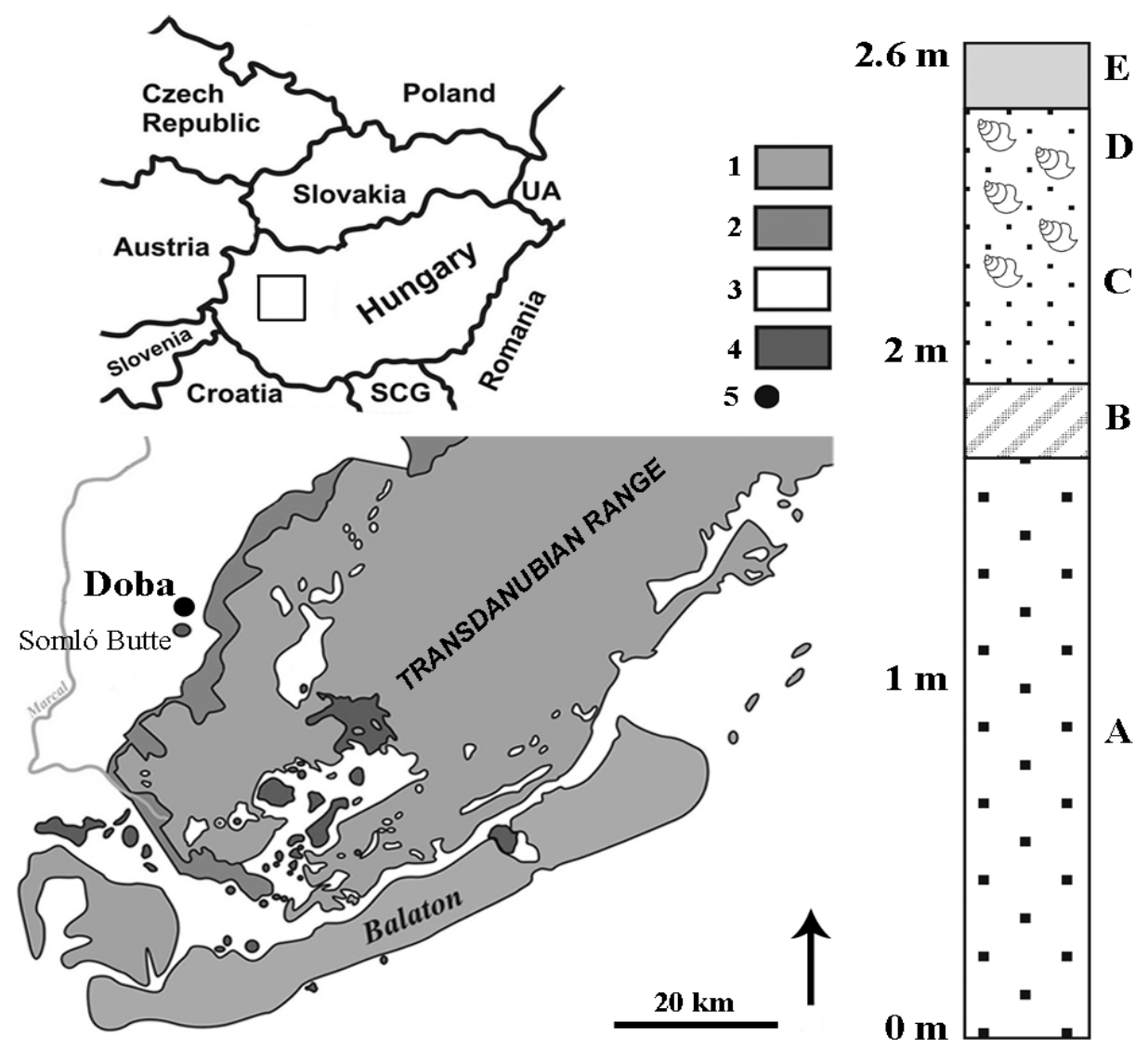

Fig. 1

Location and section of the studied outcrop of Doba in NW Hungary. 1. pre-Late Miocene basement, 2. sublittoral deposits of Lake Pannon, 3. littoral to deltaic deposits of Lake Pannon and overlying fluvial sediments, 4. Upper Miocene-Pliocene volcanics, 5. location of investigated outcrop. A: yellowish-gray medium-grained sand, B: cross-bedded medium-grained sand, C: fine-grained sand, D: fossil-bearing beds, E: soil. (after Cziczer et al. 2009)

\section{Material and methods}

About $300 \mathrm{~kg}$ of sediment from the fossiliferous layer were sampled and processed for otoliths. Samples were soaked in warm water, and after dissolution of the matrix, were screen-washed (smallest mesh size: $0.5 \mathrm{~mm}$ ). Larger otoliths were picked by naked eye, the remaining residue was examined under binocular microscope for smaller specimens. Altogether, 173 otolith specimens were recovered. Their preservation is fair; the majority of the specimens are eroded. All described material is deposited in the Natural History Museum of the Bakony Mountains, Zirc. 

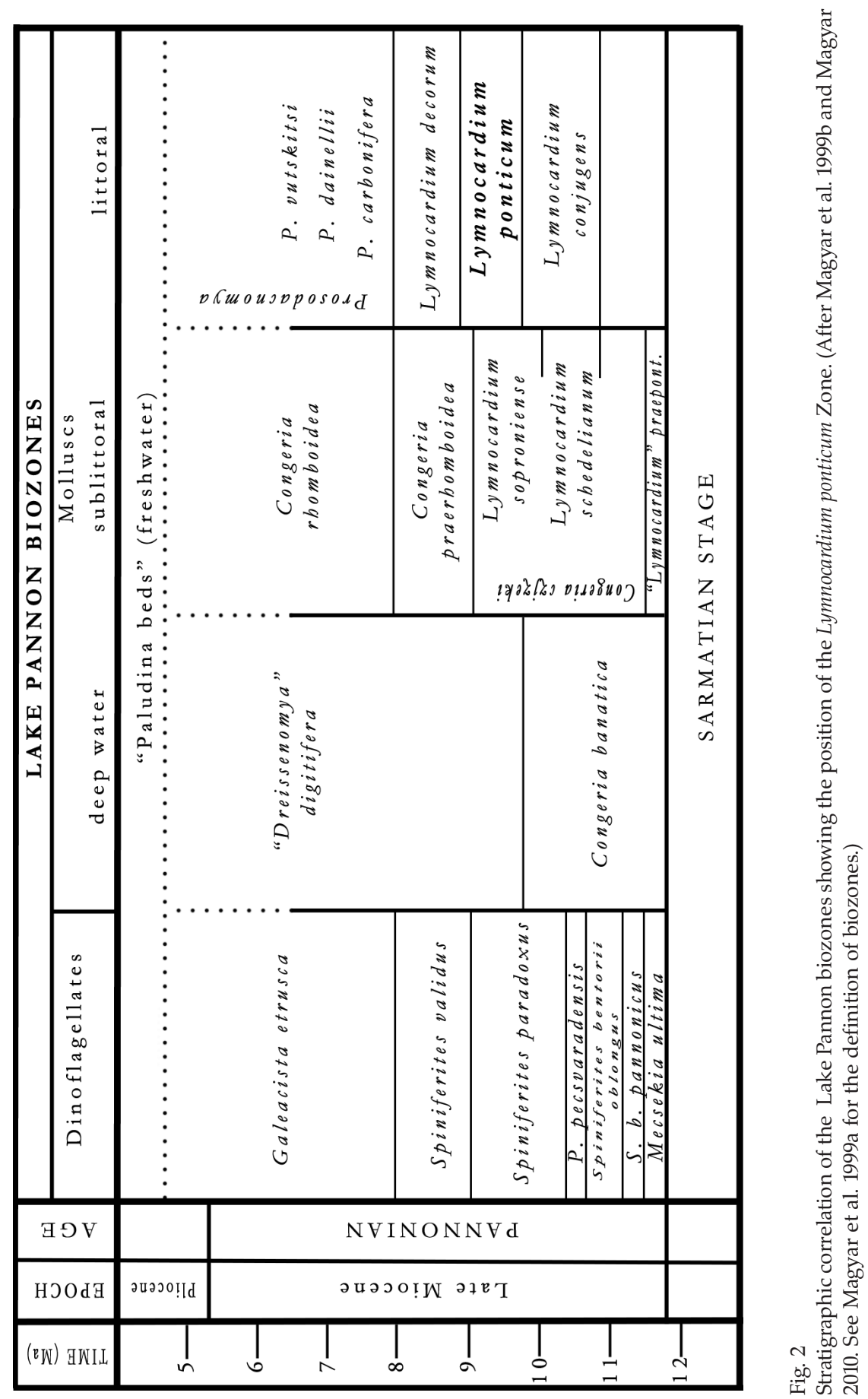

Central European Geology 55, 2012 


\section{Systematic Part}

The systematic classification follows Nolf (1985).

Superclass Osteichthyes Huxley, 1880

Class Actinopterygii Cope, 1887

Order Gadiformes Goodrich, 1909

Family Gadidae Rafinesque, 1810

Gadidae indet.

Pl. I, Figs 9, 10

Material. 6 specimens, Inv. No. 2012.10.02

Description. Otoliths are strongly eroded. The largest specimen is elongated; the others are stumpier. The anterodorsal part is wider than the posterodorsal. The rims are nearly crenulated, poorly preserved with distinct predorsal and postdorsal angles. The anterior margin is rounded; the posterior is slightly pointed. The outer face is raised longitudinally; the inner face is flat and possesses a wide sulcus. The ventral line is distinct on the small specimens, and unclear on the largest one.

Remarks. It may be hypothesized that the investigated forms belong to "genus Gadidarum" ponticum Weinfurter (1954) described from the Late Miocene of the Vienna Basin. Nolf's opinion about this taxon is that it "cannot be evaluated on the basis of the iconography" (Nolf 1985). The investigated specimens have some characteristics in common with the Miocene Gadiculus labiatus Schubert 1905, but in contrast to this species their anterior part is less rounded, without a notch and the upper edge of the sulcus is more curved, showing a sharper angle.

Remarks. Poorly preserved gadid otoliths are known from the Late Miocene of the Vienna Basin (Weinfurter 1954), Orešac (Jovanović et al. 2010), Gazovnjik, Begaljica, (Serbia), and Bodogaia (Romania) (Bosnakoff 2011).

Order Perciformes Bleeker, 1859

Family Moronidae Fowler, 1907

Genus Morone Mitchill, 1814

Morone kuehni? (Weinfurter, 1954)

Pl. I, Figs 7, 8, 13

?1954 Otolithus (Sparidarum) kühni n. sp. - Weinfurter, p. 35, taf. 6, figs 39, 40.

1954 Otolithus (Sparidarum) kühni gracilis n. sp. n. ssp. - Weinfurter, p. 35, taf. 6, figs 41, 42.

1985 Morone kuhni gracilis - Brzobohatý and Pană, p. 427, tab. 12.

? Morone kuhni (Weinfurter, 1954) - Nolf, Pl. P 175.

Material. 5 specimens, Inv. No. 2012.10.04 
Description. The available material consists of small and thin otoliths which are relatively flat with an elongated, irregular hexagonal shape. The dorsal and posterior rims are crenulated. The rostrum is blunt; the excisura is developed. The sulcus consists of a rectangular-shaped ostium, and a long and narrow cauda. The cauda is twice as long as the ostium. The straight cauda is slightly bent ventrally at its posterior end. The straight and narrow depression is situated above the crista superior, along almost the entire length of the cauda. The ventral furrow is indistinct. The inner face is slightly convex; the outer face is concave and ornamented with radial grooves and humps.

Remarks. These well-preserved specimens agree well with figures of Otolithus (Sparidarum) kuehni gracilis. Unfortunately, its holotype seems to have been lost. Brzobohatý and Pană (1985) mentioned these species as Morone from Vösendorf, but without figures. Although the investigated otoliths are more elongated, and their cauda is not bent as the holotype of Morone kuehni illustrated by Weinfurter (1954) and Nolf (unpublished manuscript of the new Otolith Atlas, by courtesy of the author), they can be assigned to this species until more material becomes available to split the taxon adequately.

Other occurrences. The species occurs in the Late Miocene only, and is also known from the Vienna Basin (Austria). The first author found a poorly preserved specimen in the collection of the Natural History Museum of Belgrade, which is from the Upper Miocene of Begaljica (Northern Serbia) and may also belong to this taxon.

\author{
Family Sciaenidae Gill, 1861 \\ Sciaena Group \\ Genus Umbrina Cuvier, 1817
}

Umbrina cirrhosoides (Schubert, 1902)

Pl. I, Fig. 4, 6

\footnotetext{
v 1902 Otolithus (Corvina?) cirrhosoides n. sp. - Schubert, p. 304, pl. X, figs 4a, b.

v 1902 Otolithus (Umbrina?) plenus n. sp. - Schubert, p. 304, pl. X, figs 6a, b, c.

1993 Umbrina cirrhosoides (Schubert, 1902) - Schwarzhans, p. 77, figs 124, 125.

? 1954 Sciaena angulata Schubert, 1902 - Weinfurter, p. 37, pl. 6, figs 33, 34.

pars 2008 Umbrina cirrhosoides (Schubert, 1902) - Bosnakoff, p. 223, pl. I, figs 1-4, non 5-7.

v 2010 Umbrina cirrhosoides (Schubert, 1902) - Jovanović et al., p. 73, pl. II, fig. 3.
}

Material. 24 specimens, Inv. No. 2012.10.03

Description. Slightly eroded, adult and juvenile specimens. The otoliths have a rounded rectangular shape. The dorsal rim is nearly horizontal, characterized by a tip above the junction of the ostium and the cauda. The dorsal rim terminates in a rounded posterodorsal angle. The inner face is rather convex; the outer face is concave and strongly thickened in the posterior part. No umbo is present. 
The ostium is large and rounded, characterized by a narrowing of the anterior part. The upper margin of the ostium runs close to the dorsal rim of the sagitta. The cauda is shallow, anteriorly straight and then turns in the ventral direction, terminating slightly bending to the front. The curved cauda encompasses a hump.

Other occurrences. U. cirrhosoides is known from the Middle and Late Miocene of the Vienna Basin (Austria) and Orešac (Late Miocene, Serbia).

\section{Umbrina sp.}

\section{Pl. I, Fig. 5}

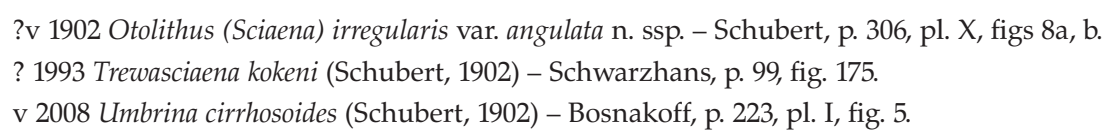

Material. 4 adult and subadult specimens, Inv. No. 2012.10.06

Description. Sagittae have a rounded rectangular, elongated shape; the smaller specimens have crenulated rims. The inner face is slightly convex; the outer face is flat.

The sulcus is divided into a large and rounded ostium and an intensely curved cauda. The ostium is thinner in the middle; the cauda drops down vertically along the posterior rim and terminates near to the ventral rim with a shallow groove. An umbo is present in the center of the outer face.

Remarks. These specimens are very similar to the subspecies described as $U$. irregularis angulata (Schubert 1902), but the holotype (see Pl. I, Fig. 6) is eroded and not suited for species identification.

Other occurrences. This form occurs in the Late Miocene only, also known from the Vienna Basin (Brunn) and the deposits of Lake Pannon (Budapest-Kőbánya).

\section{Umbrina aff. cirrosa (Linnaeus, 1758)}

\section{Pl. I, Figs 1-3}

v 2008 Sciaena sp. /Bosnakoff, p. 223, pl. I, figs 8, 10, pl. II, fig. 3.

v 2009 Umbrina aff. cirrosa (Linnaeus, 1758) - Cziczer et al., p. 16, fig. 12.

Material. 47 specimens, Inv. No. 2012.10.07

Description. It is a drop-shaped otolith, with the anterior part being more rounded and its posterior part being narrower than that of $U$. cirrhosoides. The dorsal rim is blunt and flattened in the middle. The ostium is large and rounded, filling almost completely the anterior part of the inner face. The cauda is shallow and curved; the lengths of the horizontal and vertical parts are equal.

Remarks. The morphology of the inner face is very similar to both the extant species Umbrina cirrosa (Linnaeus, 1758) and Sciaena umbra Linnaeus, 1758, but the 
outer side of Umbrina aff. cirrosa is flatter, and has no umbo. The greatest difference from Umbrina cirrosa (Linnaeus, 1758) is seen in the outline of the ostium and in the undulate posterior part of the dorsal rim. The specimen described by Böhme as Umbrina aff. cirrosa from Tata, western Hungary (Böhme in Cziczer et al. 2009), apparently also belongs here. To describe this form as a new species, more and better preserved material would be needed.

Other occurrence. Late Miocene, Tata (Hungary).

"genus aff. Umbrina" kokeni (Schubert, 1902) Pl. I, Figs 11, 12

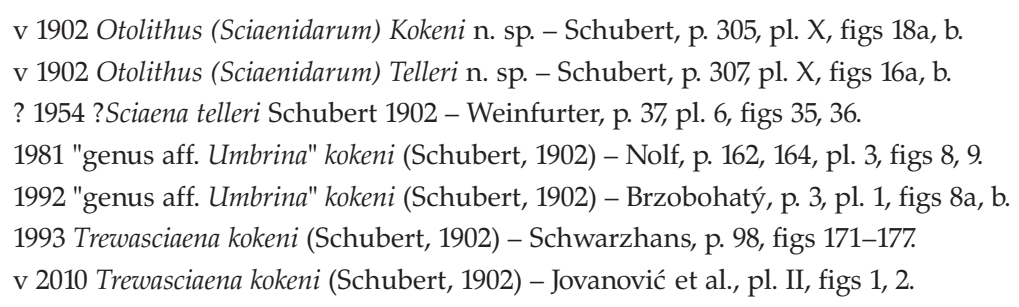

Material. 11 juvenile and subadult specimens, Inv. No. 2012.10.05

Description. The sagittae are robust, elongated and rectangular; the dorsal rim is strongly sinuous in dorsal view. The inner face is convex; the outer face is slightly convex and wrinkled. The ostium is elongate. The cauda is slightly bent at the posterior rim, and ends in a tip.

Other occurrences. The species occurs in the Late Miocene only, also known from the Vienna Basin (Götzendorf, Brunn, Vösendorf, Siebenhirten, Leobersdorf), and Orešac (Serbia).

\section{Results and discussion}

Composition of the fish fauna from Doba

The fauna consists of six taxa representing three families: Sciaenidae, Gadidae and Moronidae. Many otoliths of juvenile individuals were not suitable for species identification, and the same applies to corroded specimens.

Neritic sciaenid fishes of the genus Umbrina dominate in the assemblage. $U$. cirrhosoides Schubert 1902 is known from the Middle and Late Miocene of the Vienna Basin (Schubert 1902). Umbrina sp. differs from all known Umbrina species. The third Umbrina species is very similar to the extant $U$. cirrosa (Linnaeus 1758), but it likely represents a new species. However, to establish that it is indeed a new endemic form requires more evidence. The fourth sciaenid species, "genus aff. Umbrina" kokeni (Schubert 1902), is also known from other Late Miocene localities of the Vienna Basin (Schubert 1902; Schwarzhans 1993) and Lake Pannon 
(Jovanović et al. 2010). Doba is the first known locality, where all the Umbrina species mentioned above occur together.

Other fish taxa apart from sciaenids are rare: six specimens belong to a possibly deep-neritic Gadidae and five to the shallow-neritic Moronidae. These forms seem to differ from both recent and other Miocene gadid and moronid species. Similar forms are only known from the Vienna Basin, and uncertain, poorly preserved gadid specimens have been found in the collection of the Natural History Museum of Belgrade, coming from the Late Miocene of northern Serbia (Jovanović et al. 2010).

\section{Paleoecology of the fish fauna from Doba}

Sciaenid otoliths dominate the fish assemblages of Lake Pannon deposits (Schwarzhans 1993). Sciaenidae are small to large-sized bottom-dwelling fishes, typically benthic carnivores feeding on invertebrates and small fishes. They are found in both marine and freshwater environments, primarily in estuaries and muddy river banks under warm temperate and tropical climate. Adult Umbrina cirrosa (Linnaeus 1758) prefers coastal water (0-100 m water depth), while its juveniles live in estuaries (Cziczer et al. 2009).

The recent Gadiculus argenteus Guichenot, 1850, which is a deep-water (100-1000 $\mathrm{m})$, pelagic-oceanic, non-migratory species (Cohen et al. 1990), presumably is the closest relative of this gadid species.

All these fishes are predators; thus this otolith assemblage is far from representing the entire ancient fish fauna. Prey fish remnants (otoliths) have not been identified in the Doba record so far. The studied otolith association is similar to otolith associations from other localities of Lake Pannon deposits. Doba is the richest known locality of Late Miocene otoliths in the Carpathian Basin, due to the large sample size and careful processing. Based on a comparison with modern data, the paleoecology of the otolith assemblage points to shallow coastal, estuarine environment conditions. Complete paleoecological interpretation requires additional environmental information, such as the otolith increment analysis (Kern et al. 2012) or the composition of the mollusk fauna (Katona and Magyar in prep.) provide.

\section{Acknowledgements}

This study was supported by the Natural History Museum of the Bakony Mountains (Zirc, Hungary). Special thanks are due to Tibor Berta for his help in the field work. Many thanks to Irene Zorn (Geologische Bundesanstalt, Wien) for assistance with the type material described by Schubert. The primary author is indebted to Dirk Nolf (Institut royal des Sciences naturelles de Belgique, Brussels) for his detailed comments on earlier versions and to Bettina Reichenbacher for a constructive review. Thanks to Rostislav Brzobohatý (Masaryk University, Brno) 
for his helpful advice. The primary author is grateful to colleagues in the Research Group for Paleontology of the Hungarian Academy of Sciences for their constant support and warmly thanks Gordana Jovanović and Dragana Durić (Natural History Museum, Belgrade) for their kind assistance with the collection in Belgrade. We wish to express our gratitude to Imre Magyar (MOL Hungarian Oil and Gas Plc.) for his kind help and useful suggestions on the text.

\section{Plate I}

Fig. 1. Umbrina aff. cirrhosa, right sagitta, a: inner face, b: outer face, c: dorsal view Fig. 2. Umbrina aff. cirrhosa, left sagitta, a: inner face, b: outer face, c: ventral view

Fig. 3. Umbrina aff. cirrhosa, right sagitta, a: inner face, b: outer face, c: ventral view

Fig. 4. Umbrina cirrhosoides (Schubert, 1902), right sagitta

Fig. 5. Umbrina sp., left sagitta, a: inner face, b: outer face, c: ventral view

Fig. 6. Otolithus (Sciaena) irregularis var. angulata Schubert, 1902, holotype, right sagitta, inner face

Fig. 7. Morone kuehni? (Weinfurter, 1954), left sagitta

Fig. 8. Morone kuehni? (Weinfurter, 1954), right sagitta

Fig. 9. Gadidae indet. left sagitta

Fig. 10. Gadidae indet. right sagitta

Fig. 11. "genus aff. Umbrina" kokeni (Schubert, 1902), right sagitta, a: inner face, b: outer face

Fig. 12. "genus aff. Umbrina" kokeni (Schubert, 1902), left sagitta, a: inner face, b: outer face 
A fish otolith assemblage from the Late Miocene deposits of Lake Pannon (Doba, NW Hungary) 145

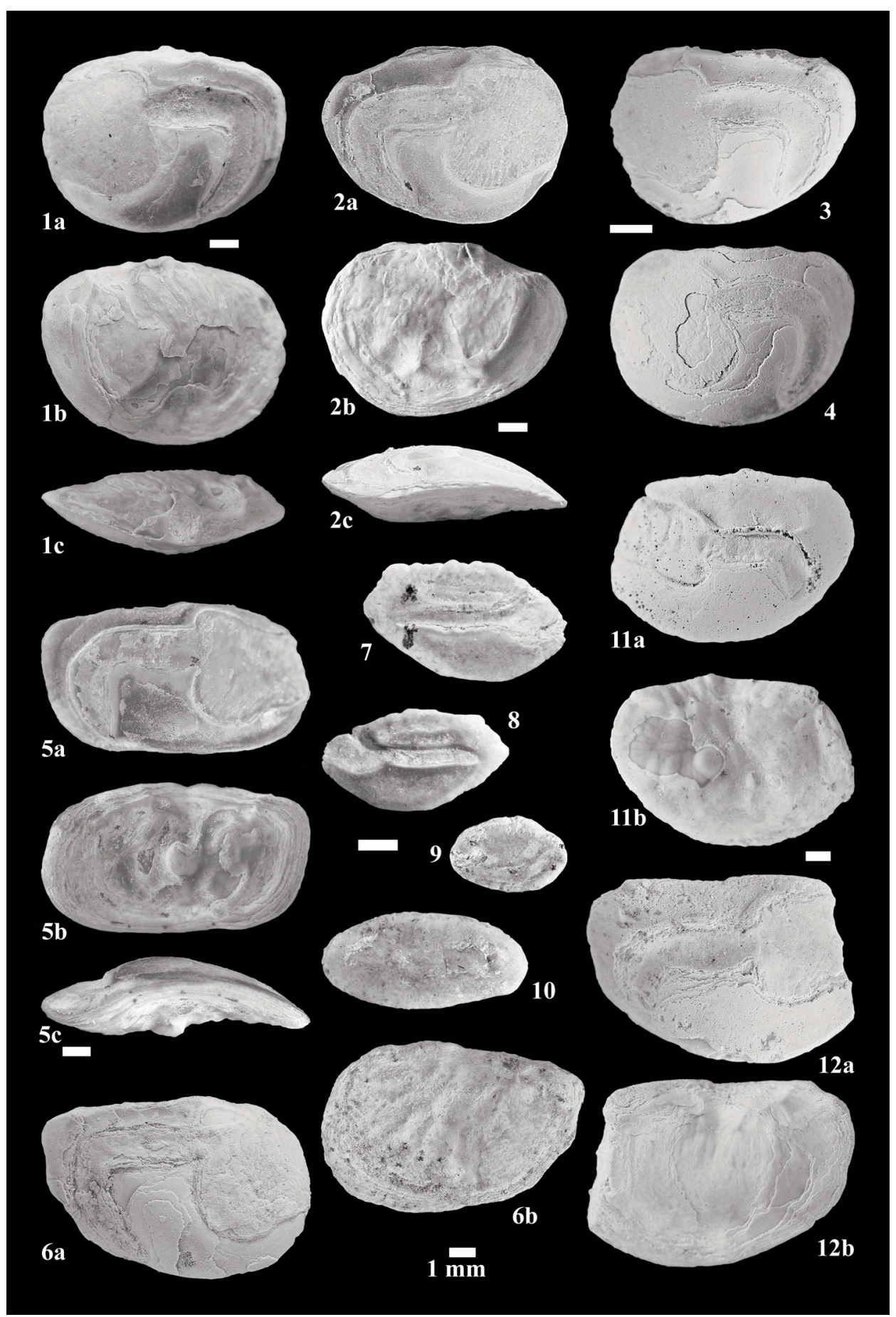

Central European Geology 55, 2012 


\section{References}

Bosnakoff, M. 2008: Late Miocene (Pannonian) sciaenid fish otoliths from Hungary - preliminary studies. - 125th Anniversary of the Department of Palaeontology of the Eötvös University, A Jubilee Volume, Hantkeniana, 6, pp. 219-228.

Bosnakoff, M. 2011: Checklist of the Fossil Fish Otoliths in the Department of Paleontology and Geology, Hungarian Natural History Museum. - Fragmenta Palaeontologica Hungarica, 29. pp. 49-68.

Brzobohatý, R. 1992: Otolithen aus dem Obermiozän, Pontien, des Wiener Beckens (Götzendorf und Stixneusiedl, NÖ). - Annalen des Naturhistorischen Museums in Wien, 94A, pp. 1-6.

Brzobohatý, R., I. Pană 1985: Die Fischfauna des Pannonien. - In: Papp, A., Á. Jámbor, F.F. Steininger (Eds): Chronostratigraphie und Neostratotypen Miozän der Zentralen Paratethys. M6 Pannonien, pp. 426-431.

Cziczer, I., I. Magyar, R. Pipík, M. Böhme, S. Ćorić, K. Bakrač, M. Sütő-Szentai, M. Lantos, E. Babinszki, P. Müller 2009: Life in the sublittoral zone of long-lived Lake Pannon: paleontological analysis of the Upper Miocene Szák Formation, Hungary. - International Journal of Earth Sciences, 98/7, pp. 1741-1766.

Cohen, D.M., T. Inada, T. Iwamoto, N. Scialabba 1990: FAO Species Catalogue. Vol. 10. Gadiform fishes of the world (Order Gadiformes). An annotated and illustrated catalogue of cods, hakes, grenadiers and other gadiform fishes known to date. - FAO Fisheries Synopsis 125/10. 442 p.

Jovanović, G., S. Knežević, Đ. Djurić, M. Bosnakoff, G. Paunović 2010: Upper Miocene fauna of Orešac near Smederevo (Serbia). - Bulletin of the Natural History Museum in Belgrade, 3, pp. 67-93.

Kern, Z., M. Kázmér, M. Bosnakoff, T. Váczi, B. Bajnóczi, L. Katona 2012: Incremental growth and mineralogy of Pannonian (Late Miocene) sciaenid otoliths - palaeoecological implications. Geologica Carpathica, 63/2, pp. 175-178.

Magyar, I. 2010: A Pannon-medence ősföldrajza és környezeti viszonyai a késő miocénben (forditas?). - GeoLitera, Szeged, $140 \mathrm{p}$.

Magyar, I., D.H. Geary, M. Sütő-Szentai, P. Müller, M. Lantos 1999a: Integrated biostratigraphic, magnetostratigraphic and chronostratigraphic correlations of the Late Miocene Lake Pannon deposits. - Acta Geologica Hungarica, 42/1, pp. 5-31.

Magyar, I., D.H. Geary, P. Müller 1999b: Paleogeographic evolution of the Late Miocene Lake Pannon of Central Europe. - Palaeogeography, Palaeoclimatology, Palaeoecology, 147, pp. 151-167.

Nolf, D. 1981: Révision des Types d' Otolithes de Poissons Fossiles décrits par R. Schubert. Verhandlungen der Geologischen Bundesanstalt, Wien, 1981/2, pp. 133-183.

Nolf, D. 1985: Otolithi Piscium. - Fischer Verlag, Stuttgart, New York, 145 p.

Schubert, R.J. 1902: Die Fischotolithen des österr-ungar. Tertiärs I. - Jahrb. k. k. Geol. Reichsanst., 51, pp. 301-315.

Schubert, R.J. 1906: Die Fischotolithen des österr-ungar. Tertiärs III. - Jahrb. k. k. Geol. Reichsanst., 563-4, pp. 623-706.

Schwarzhans, W. 1993: A comparative morphological treatise of recent and fossil otoliths of the family Sciaenidae (Perciformes). Piscium Catalogus: Part Otolithi Piscium, 1. - Verlag Dr. Fiedrich Pfeil, München, 245 p.

Strausz, L. 1942: Das Pannon des mittleren Westungarns. - Annales Historico-Naturales Musei Nationalis Hungarici, 35, pp. 1-102.

Szilaj, R., M. Szónoky, P. Müller, D.H. Geary, I. Magyar 1999: Stratigraphy, paleoecology, and paleogeography of the "Congeria ungulacaprae beds" (=Lymnocardium ponticum Zone) in NW Hungary: study of the Dáka outcrop. - Acta Geologica Hungarica, 42, pp. 33-55.

Weinfurter, E. 1950: Die oberpannonische Fischfauna vom Eichkogel bei Mödling. - Sitz-ber. Öster. Akad. Wiss. Math.-naturwiss. Klasse, Abt. I, 159, pp. 37-50.

Weinfurter, E. 1954: Pisces. In: Papp, A., E. Thenius (eds): Vösendorf - ein Lebensbild aus dem Pannon des Wiener Beckens. - Mitteilungen der Geologischen Gesellschaft Wien, pp. 30-40. 